\title{
Islamic Education Teachers' Content Knowledge of Islamic Law Matters: A Study in Yogyakarta City
}

\author{
Ahmad Darmadji \\ Department of Islamic Education and Postgraduate Program, Faculty of Islamic Studies,Islamic University of Indonesia \\ Yogyakarta, Indonesia; Email: ahmad.darmadji@uii.ac.id
}

Syarief Zubaidah

Department of Islamic Law and Postgraduate Program, Faculty of Islamic Studies Islamic University of Indonesia, Yogyakarta, Indonesia

\begin{abstract}
M. Roem Sibly
Center of Islamic Studies, Islamic University of Indonesia, Yogyakarta, Indonesia
\end{abstract}

Yuli Andriansyah

Department of Islamic Economics, Faculty of Islamic Studies, Islamic University of Indonesia, Yogyakarta, Indonesia

\section{Doi:10.5901/mjss.2015.v6n5p441}

\section{Abstract}

This paper was aimed to analyze Islamic education teachers' content knowledge of matters related to Islamic law. A crosssection survey research was conducted on twenty Islamic education teachers in several schools in Yogyakarta City pursuing master study in Postgraduate Program, Faculty of Islamic Studies, Islamic University of Indonesia. Respondents can be characterized as teachers with civil servants status, having minimum of five years teaching experience, mostly active in social mass organizations. The result shows that respondents have relatively low familiarity with sources of Islamic law, especially the classical ones. Other result also indicate low content knowledge in teachers about matters related to Islamic law, especially in economics and heredity. From the results, the research suggests a more active role in both government and higher education institutions to contribute in improving teachers' knowledge. Contributions proposed can mainly be formed in training of teachers and creating useful website with Islamic education contents for their teaching sources.

Keywords: Islamic education teachers, content knowledge, Islamic law matters

\section{Introduction}

As a country with the world largest Muslim citizens, the government of Indonesia has been integrating Islamic education in its school curriculum from elementary until senior high levels. Under joint supervision of the Ministry of Religious Affairs and the Ministry of National Education (currently named Ministry of Education and Culture), both public and private schools nationally provide two hours per week Islamic education for Muslim students (Pohl, 2015). This integration was also be improved by many hidden curriculum in the form of Islamic activities in schools. Such efforts were viewed as important tools to increase the understanding and practicing of Islamic values in the heart of students and their daily life. It is noteworthy that other religious educations were also provided by the government in accordance with the need of such educations in many schools.

Although Islamic education has been an integrated part of national curriculum and students daily activities, recent trends in sensitive issues related to some group of Muslims such as terrorism, radicalism, and violence simply put the relevance of Islamic education in question. People might have been asking what materials taught in the class that lead students in the future become extreme, intolerance, and anarchists. The materials of Islamic education was not or at least not the only reason behind many negative attitudes young generations show recently. However, because of its important role in disseminating Islamic values to young citizens, Islamic education as commonly taught subject can always be targeted as topic of discussions or even debates. 
Such negative stereotype to this situation also finds its momentum as a report by Center for Religious Freedom \& Institute for Gulf Affairs (2006) reveals how Saudi Arabia's textbooks continues to propagate an ideology of hate toward the "unbeliever". In these textbooks circulated for public schools in the country, unbeliever refers not only to those who adhere other religion than Islam such as "Christians, Jews, Hindus, atheists and others", but also covers "Shiites, Sufis, Sunni Muslims who do not follow Wahhabi doctrine".

Matsumoto's (2008) insights on how historically education has its own contribution in seeding conflict in Afghanistan as well as in building peace in post-conflict imply significant role of education within Muslims society. For Indonesian context, Rokhmad (2012) noted that education institutions can be penetrated by radical thoughts. He also reveals that some the textbooks and work books also contain numerous declarations that could inspire Muslim students' hatred against their counterparts: non-Muslim students. Very recently, Ministry of Religious Affairs draws some Islamic education textbooks that spread hatred to other religions (Republika, 2015). These fact infer further challenge in making Islamic education fruitful tool to provide humanity with its peace and love teachings.

One of the most important agent to guarantee the success of Islamic education in bringing peace in Muslim society is teacher. Teacher plays important role in delivering understandings of religious aspects including doctrines, practices, and history to students. As for a teacher, an honored profession in Islam, his or his position was an example for students which make the existence of this profession more crucial. Such ideal was mostly based on philosophical basis of Islamic education which see student as subject that throughout the teaching process should be a 'whole person' in his or her 'physical, intellectual, moral, and spiritual dimensions' (Daun \& Arjmand, 2005). In other words, Samsuddin (2012) stated Islamic education purposes are to sharpen students' mind and to soften their heart.

As Mirza \& Bakali (2010) noted teachers today need to have proper knowledge about Islam and its basic teachings as well as current affairs its adherers face especially in the aftermath of September 9, 2001 event which have brought Muslims and the world a new way of life. Proper understanding is required by teachers so that the religion can be accurately described when it was addressed by students. Although Mirza \& Bakali (2010)'s point of view was particularly in the context of society in the North America, it was and will always be relevant for Indonesia since Islam can be viewed from normative and historical perspectives.

This paper was part of a longitudinal planned research aimed to revitalize Islamic education teaching in schools in Indonesia. As first effort in the series research to come, this current paper presents a study on content knowledge of Islamic education teachers in Yogyakarta City, Yogyakarta Special District. The future research will deal issues such as textbooks contents, curricula, and school management. As an early endeavor to understand current state of Islamic education, this paper focus on teachers' content knowledge since their capacity in delivering ideas as well as creating an exemplary to students is undeniable.

To make the paper concise, the structures of this study will be as follow. This section introduce the background of the study along with its purpose and its position in the sequence of further research. Section two will detail relevant theoretical framework of the research and previous works related. In section three, methods of research will be explore to guarantee its scientific process. Results of research along with its discussion will be given in section four. Last section will conclude the research along with its limitations and further agenda of its continuity.

\section{Literature Review}

Literature review in this section will explore basic theoretical framework used in this research and recent trends in research on teachers and their relation with textbooks and their knowledge about its contents. To ensure that the current research is free of repetition of any other previous research as well as to provide insightful state of the art, findings from international and Indonesian researchers' work will be briefly reviewed.

This paper rely mostly on Shulman's (1986) well-known perspective on teacher knowledge. Shulman suggested three categories of content to understand teachers' knowledge: '(a) subject matter content knowledge, (b) pedagogical content knowledge, and (c) curricular knowledge'. Subject matter content knowledge or simply content knowledge refers to 'the amount and organization of knowledge per se in the mind of the teacher'. Schwab's (1978) 'distinction between substantive and syntactic structures of knowledge' can be referred as representation of this content knowledge.

Schwab (1978) points that subject consists of both its substantive and syntactic structures. The first structure can be defined as the range of techniques in which the fundamental perceptions and standards of the discipline are formed to integrate its facts. While the second structure refers to the agreed method to formulate 'truth or falsehood, validity or invalidity'. From this point of view, Schwab (1978) argues that a teacher should not only capable to explain agreed terms in subject he or she teaches but also to demonstrate specific reason behind it. A teacher is also obliged to enlighten students on relations between terms in the subject along with its environment both theoretically and practically. 
Using Shulman's content knowledge and Schwab's structures of knowledge in the context of Islamic education in Indonesia means that an ideal teacher must be able to understand basic principles of Islam as well as to practice it properly. In other word, teachers are required to approach the material they teach both normative and historical perspectives in which the first was well written and documented in holy scripts and the second in daily context of Muslims (Susanto, 2009). Since Muslims believe their religion as a complete guide for humanity not only in this world but also in the hereafter, the scope of matter an Islamic education teacher should master is very wide. The range spreads from Islamic law regarding daily cleanness until political issues such as ideal national leader or even suitable structure of a country.

However, Shulman's content knowledge application in Islamic education is rare or even non exist since its applied example for social sciences is so far less compared to its peer in sciences and mathematics. To mention the examples, some works in sciences and mathematics have been conducted by Tsangaridou (2002), Schneider \& Plasman (2011), and Stoilescu (2015). Some developments have also been made in relation to content knowledge applied to expanding fields of education especially in the context of technology, environment, and other specific subjects. Many researchers focus their studies on technological pedagogical content knowledge (TPACK) in term of its framework of theoretical basis (Graham, 2011), validity (Archambault \& Barnett, 2010) and critical examination (Stoilescu, 2015), integration with information and communication technologies (Chai, Koh, Tsai, \& Tan, 2011) and its scale (Yurdakul, et al., 2012).

Abdullah \& Halim (2010) suggested teachers' lack of pedagogical content knowledge as main cause of lack of students understanding of environmental education in Malaysia and developed an instrument to improve it. A case study science of science teachers in Thailand reveals that their construction representation (CoRe) can be helpful for their understanding on content knowledge as well as for classroom activities in materials related to global warming(Chordnork \& Yuenyong, 2014).

Furthermore, Bertschy, Künzli, \& Lehmann (2013) proposed two model for future education for sustainability: Curriculum, Sustainable Development, Competences, Teacher Training (CSCT) and The Competences in Education for Sustainable Development (ECE). Teachers, as they find, should have sufficient requirements to teach ESD from both their educational background and further educational development.

In the absence of relevant research on content knowledge from Islamic education perspective, this literature review section will deal with research on Islamic education and teachers in Islamic countries. Research on teachers in Islamic countries or communities has be carried by many researchers in several topics such their perspective on complex issues. Cashman's (2007) case study on Malaysian teachers' perspectives on the Iraq war for example reveals their opinion that the United States neglected dialogue in dealing with terrorism. This may lead to another lack of support in the war against terror the United States promote since many moderate Muslims believe Islam is religion of peace and solution to terrorism should also keep human dignity. At this point, voices from teachers and students in other country has potential and important implication for future policies regarding international matters (Cashman, 2007).

In his research on Muslim teachers' conceptions of evolution, Clément's (2015) result shows it is not that simple to answer whether Muslim countries, and Muslim teachers, more creationist than other ones. His analysis finds the absence of "specific effect of the Muslim religion itself on the teachers' conceptions of evolution". Other result also shows that correlation between knowledge and values in Muslim teachers' conceptions of evolution is still open for discussion and not implying causality. These two research can be a solid background to state that Muslim teachers as well as many other Muslims are not at ease to come to conclusion about many matters in their life. Many factors, not only religion, affect their perspectives, attitudes, and perceptions which imply judging Muslims as single entity is not a just.

Many Indonesians have paid intensive attentions to research dealing with Islamic education along with teachers and students as its subject. A case study research in a junior high school suggests significant correlation between Islamic education learning completeness and students' cognitive maturity. Such empirical finding is important since cognitive maturity greatly affects the learning process (Ardi \& Suharyat, 2011). As for the number, Mukminan's (2010) research in Bantul Regency, neighboring local government of Yogyakarta City, indicates the adequacy of teacher in accordance to Minister of National Education Regulation Number 39/2009. This indicate sufficient human resources in teaching Islamic education in relatively close to city area such as Bantul Regency. Such condition can be hard to afford for other schools in rural and back country area.

Many researchers pay more attention on the materials as well as in the method of teaching of Islamic education. Islamic education teaching was viewed as material understanding oriented and normative. Therefore, some suggestions were proposed such as increasing social reconstruction concept on the materials teaching (Suneti, 2012), inception of national characteristics as teaching orientation (Hidayat, 2012), applying contextual (Sahlan, 2011) and hermeneutic (Syafi'i, 2012) approaches in teaching process. These studies imply the need of contextualization for Islamic education to meet the current globalization and interconnectedness challenge. 
Another issue as Rasyidin (2010) suggests is the biased materials to women in some Islamic education textbooks used in elementary schools. This gender bias take its form in marginalization, subordination, negative labelling and many other sensitive issues to women. As comparison, higher education Islamic education textbooks in Indonesia according to Hanafi (2011) still focus its study as single entity, isolating itself from other branches of sciences. Furthermore, Baidhawy (2014) argue the need of Islamic education to promote peace values in teaching students since they all live a very plural society in which diversity is undeniable. While Salamah (2013) suggests multicultural education as a tool to bridge diversity in Indonesians characteristics to maintain inclusive values of religions.

From the description on theoretical framework and previous study above, novelty of this research can be summarized in its effort to understand and to analyze Islamic education teachers' content knowledge with reference to Islamic law matter. Such research has never been formerly conducted by both international and Indonesian researchers. Another uniqueness this paper offers is its focus on Islamic education teachers in Yogyakarta City, nationally famous city for education, culture, and destiny on students.

\section{Research Method}

The research behind this paper can be categorized as quantitative one since numerical data were collected and analyzed to understand important issues in teaching of Islamic law (Gay, Mills, \& Airasian, 2012, p. 7). This paper employed survey research to collect data to answer questions about teachers' preference in using text books in teaching process. The design used was cross-sectional survey in which the data required were collected from selected teachers at single point in time (Gay, Mills, \& Airasian, 2012, pp. 184-185) by distributing a questionnaire consisting several question about textbooks on materials they teach.

The respondents of the research were teachers of Islamic education in several elementary, junior and high schools in Yogyakarta City currently taking master course on Islamic studies in Postgraduate Program, Faculty of Islamic Studies, Islamic University of Indonesia. This group of respondents consists of 20 Islamic education teachers and were chosen as sample in this research based on consideration about available resources (Hutchinson, 2004; Shapiro, 2008).

Questionnaires distributed consist of several question regarding respondents' status and background, familiarity with sources of Islamic law, and content knowledge of Islamic law matters in Islamic education subject. Status of respondents in this questionnaire refers to type of teacher employment whether civil servant or not; source of knowledge about Islam i.e. from pursuing study in Islamic higher education or from Islamic boarding school (pesantren); type of schools where they teach; and religious understanding with relation to commonly practiced Islamic activities in society.

Familiarity with Islamic law sources is derived from questions about famous Islamic law books written by classical Islamic scholars they know or read; Islamic scholars the founders of schools of law in Islam (madhhabs); and opinion on the applicability of Islamic law in Muslims current state of affairs. Content knowledge in specific issue in Islamic law is examined by questions about what type of matter they master most and they master less; other Islamic law books sources they find it useful; and most commonly used sources in teaching.

Descriptive statistics was then used to analyze the data obtained mainly by frequencies and graphing. The results were then discussed to answer research questions about teachers' content knowledge of Islamic law materials in Islamic education subject they teach.

\section{Results and Discussion}

\subsection{Status of Respondents}

Status of respondents in general can be classified as civil servant teachers with about 13 respondents or $65 \%$ of total respondents. Four other respondents are paid-per-teaching teachers (honorer in Bahasa which probably derived from honorary but the meaning of this term in Indonesian context was not suitable) and three others are teachers appointed by the foundation of the schools. The following figure depicts respondents' status as teachers in each of their schools. 


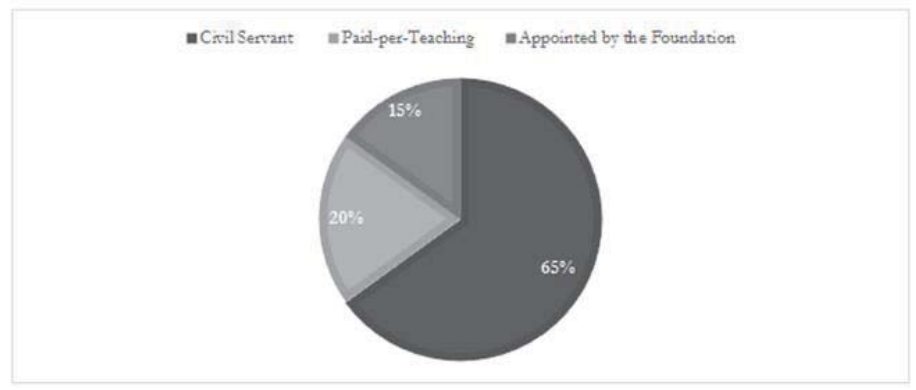

Figure 1: Status of Respondents in Their Schools Source: Primary data.

The dominant status as civil servants for respondents is important since it implies the significant role of government in Islamic education in many type of schools. Not only providing schools with Islamic education teachers with civil servant status, government's role in national education can also be seen from policy to increase quality by awarding teachers with certified skill extra payment to their salary or mostly known as sertifikasi in Bahasa. Such status as civil servants as well as extra payment are expected to contribute to teachers' enactment.

Next question regarding respondents' status is their experience in teaching. Each of respondents have teaching experience of more than five years. Seven of them have six until ten years of experience, four of them have been teaching for eleven until 15 years, and two of them have been teachers for sixteen until twenty years. The rest seven respondents have longer than twenty years in teaching.

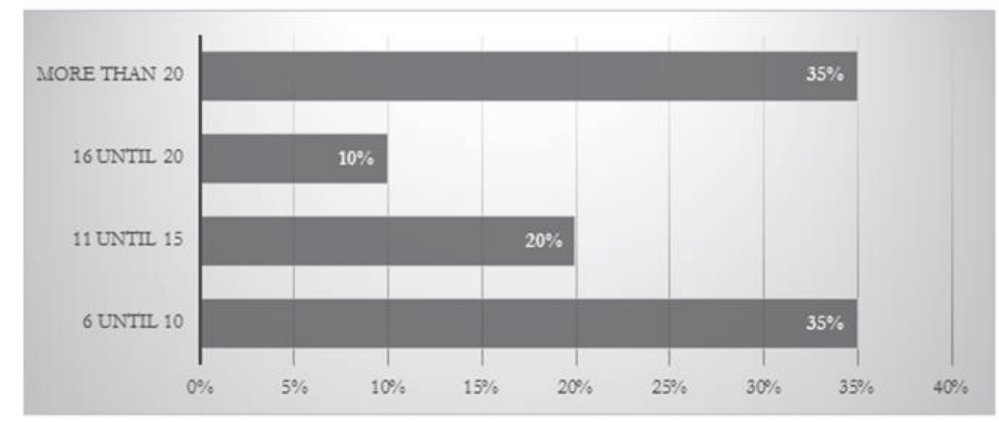

Figure 2: Respondents' Teaching Experience in Years

Source: Primary data.

Respondents of the research have long enough in teaching Islamic education subject as the figure shows above. This length of experience is potential source to advance their capacity in the subjects as well as in any other materials related. In relation to the type of schools the respondents teach, most of them, about $40 \%$, are teaching in vocational senior high schools. Respondents teaching junior high and elementary schools are $35 \%$ and $20 \%$ respectively. The rest $5 \%$ teach in senior high school.

All respondents have university degree in five years undergraduate course as it is obliged in Indonesia before taking master course. This teachers' latest education is important since it can play important role in guiding students in the classes to better understanding of Islamic education materials. As comparison, Jourdan, Pironom, Berger, \& Carvalho's research (2012) shows longer university education has 'more positive view on health' which for the case in Islamic education such result can also appear.

Respondents were also asked about their affiliation in social organization. $80 \%$ and $15 \%$ of respondents also get involved in social activities in mass organizations Muhammadiyah dan Nahdhatul Ulama respectively and only $5 \%$ of them do not involve in any of such organization. This result was in line with the fact that Yogyakarta City and Yogyakarta 
Special District in general is home for Muhammadiyah, as its establishment and growth were in this area. It is also important to note that both Muhammadiyah and Nahdhatul Ulama share the same mission as moderate Muslim organization in Indonesia that promote peace, tolerance, and against violence.

\subsection{Respondents' Familiarity with Islamic Law Sources}

Respondents were ask what Islamic law books they know at least its titles. From the answers given, respondents know about twelve books of Islamic law written in Arabic and Bahasa. Sayyid Sabiq's Fiqh Sunnah was the most well-known as represented by $30 \%$ respondents know the book. Nawawi's Riyadh Ash-Shalihin was second well-known book by $20 \%$ respondents know it. Other books along with percentage of respondents know it are Bulūgh Al-Marām, Figh Islam, AlBukhārī and Muslim's Shahīḥ (15\% respondents know the books), Averroes' Bidāyah Al-Mujtahid and Himpunan Putusan Tarjih Muhammadiyah (10\%), At-Targhīb wa At-Tahdīb, Ash-Shāfi'T's Al-Umm, Durrat An-Nāshiḥinn, Munākaḥat, and Fiqih Wanita (5\%). 25\% of respondents did not mention any of these books above.

Indonesians are mostly Sunnis in their Islamic view of theology. And for Sunni's tradition of law, Hanafī, Mālikī, Shāfi'T, and Hanbalī are the most popular classical Islamic schools of law recognized, accepted, and practiced until modern day. As for Indonesia, Shāfi'i's school of law was and is still the most widely used. Such circumstance can also be traced in the answer respondent given when they were asked about the most famous founder of schools of law they know. 50\% of respondents mentioned Shāfi'ī, $40 \%$ knew Mālikī and Hanbalī. Hanafī was well known by 30\% of respondent and only $5 \%$ of them did not mention any of four schools of law founders.

The references mention above as well as the fact that a quarter of respondent not knowing the reference books indicate respondents' the limited knowledge of classical books in Islamic law which were still used by legal entities in the court regarding Muslims' affairs. This limited knowledge was also confirmed by respondents' view that classical Islamic books should not be main sources for Islamic law in current days. $65 \%$ of respondents agree of this statement and the last 35\% still believe in classical books as the source for today's problem of law in Muslim society.

The fact that Islamic education teachers' familiarity with Islamic law sources was relatively low might be traced back to their education background especially in higher education institutions. Islamic education has been a popular major in many higher education institutions especially Islamic ones. Being major in teaching means Islamic education curricula should rely not only on Islamic contents but mostly should also depend on pedagogical skills. This perspective can also be justified by a popular proverb about teachers' role in Arabic "aț-țarīqah ahammu min al-māddah, al-ustaż ahammu min att-tarīqah" which means "method (of teaching) is more important than matter (of subject), and teacher is more important than method". This proverb was one of way to express teachers' importance above mastering method of teaching as well as matters of subject taught.

\subsection{Respondents' Content Knowledge of Matters Related to Islamic Law}

Islamic education matters taught in Indonesia consist of several topics such as Islamic law, history (tärīkh), exegesis (tafsīr), rituals (ibādah), behavior (akhlāq), hereditary (warātsah), economics (mu'āmalah) and others. The respondents were then asked about their mastery of these matters. $40 \%$ of them replied that materials related to Islamic rituals became the most mastered material, followed by $25 \%$ of respondents stated their mastery was in Islamic behavior related material. For the less-mastered materials, 35\% respondents pointed to Islamic economics and 20\% answered Islamic heredity. The fact that the two topics rely mostly on number implies that Islamic education teacher might need more extra exercise in mathematics and other relevant subject.

Respondents were then asked about teaching resources they use mostly to enhance classroom interaction. From their answers, respondents rely mostly on textbooks, website and magazines as teaching resources. Respondents were asked again about what type of books they read in order to increase their skills and knowledge. The result shows that books related to education especially Islamic education became the most read books by respondents. Education also become the most read topic in magazines or journals by respondents followed by Islamic law and psychology. However, it should be noted that about $45 \%$ of respondents do not feel necessary to add other resources than textbooks. The textbooks for them are sufficient in guiding activities in the classrooms.

These results on teachers' preference to textbooks simply imply majority of respondents' sense of need to always increase their capacity in subject they teach. These findings indicate respondents' willingness to keep what they read stay in line with their expertise although their preferences were not limited to textbooks but expanded to journals, magazines, and other books available. Since most respondents are affiliated to Muhammadiyah it is safe to say that magazine they read most could be Suara Muhammadiyah, monthly official magazine of the organization. Considering its attention to 
promote moderate Islam in Indonesia, magazine can contribute positively in sustaining teachers' perspective in teaching Islamic education matters that suit their social organization affiliation.

This research also reveals diversity in both familiarity and content knowledge which might be explained from range of duration in teachers' teaching experience as described earlier. This results thus are consistent with Kleickmann, et al.'s (2013) research which reveal significant differences in content knowledge (CK) and pedagogical content knowledge (PCK) between 'the beginning and the end of initial' mathematics teacher education.

The relatively low familiarity and content knowledge as this research show can be an important key to open higher education institutions' involvement to improve teachers' capacity. Postgraduate Program, Faculty of Islamic Studies, Islamic University of Indonesia for several times has been involved in such activities mainly with collaboration with Ministry of Religion Affairs with Islamic education teachers in Islamic schools as participants. However, since the relatively low familiarity and content knowledge can also be found in Islamic education teachers in general schools, the expanding activities to this category of teachers should also be proposed.

Another potential role higher education institutions can contribute to improve content knowledge of Islamic education teachers is by preparing relevant matters in web-based platform. It is logical since internet has been another source for teachers to find, collect, and use its content for teaching resources. Without guidance on appropriate contents for teachers from higher education especially the Islamic ones, it is very possible that teachers will access websites with radical point of view.

\section{Conclusion}

This research was conducted with respondents characterized as Islamic education teachers whose status are mostly civil servants with at least five years of teaching experience and currently pursuing study in master program. The result suggests that respondents' familiarity and content knowledge of matters related to Islamic law is relatively low, but majority of them have willingness to improve this quality. From the results some recommendation can be proposed mainly in maintaining training for teachers as well as preparing positive contents in websites to improve their knowledge.

This research has many limitations mainly in its limited size of sample and focus on Islamic law matters as part of Islamic education subject. However, decision on sample was made due to availability of resources for research and on Islamic matters was because of its status within Muslim society as the source of their faith and action. Although it has many limitation, the research starts a prospective endeavor in understanding the state of the art in Islamic education teaching in Indonesia and a futuristic project to revitalize it to improve Muslims' quality of life in the form of education.

Further research can be proposed in the same topic with wider subjects and from different areas. Other research in contents of Islamic education teaching can also be proposed for further development since it is the source of teachers' and students' understanding of Islamic teaching in the first place. Finally, research on how curricula of Islamic education in Indonesia should also be carried to understand current patterns in education process as a whole to meet Muslims student need in the globalized world as well as to meet Islamic mission for humanity.

\section{Acknowledgments}

The authors thank Center of Social Sciences and Humanities Research, Directorate of Research and Community Service, Islamic University of Indonesia for funding the research with ID Number D-DPPM-031 by which this paper was based on. The authors also thank Faculty of Islamic Studies, Islamic University of Indonesia for providing required resources in preparing this paper.

\section{References}

Abdullah, S. I., \& Halim, L. (2010). Development of Instrument Measuring the Level of Teachers' Pedagogical Content Knowledge (PCK) in Environmental Education. Procedia - Social and Behavioral Sciences, 9, 174-178. doi:10.1016/j.sbspro.2010.12.131

Archambault, L. M., \& Barnett, J. H. (2010, December). Revisiting Technological Pedagogical Content Knowledge: Exploring the TPACK Framework. Computers \& Education, 55(4), 1656-1662. doi:10.1016/j.compedu.2010.07.009

Ardi, D. S., \& Suharyat, Y. (2011, January). Hubungan antara Ketuntasan Belajar Pendidikan Agama Islam dengan Kematangan Kognitif Siswa [Correlation between Islamic Education Learning Completeness and Student Cognitive Maturity]. Turats, 7(1). Retrieved from http://www.ejournal-unisma.net/ojs/index.php/turats/article/view/84

Baidhawy, Z. (2014, December). Pendidikan Agama Islam untuk Mempromosikan Perdamaian dalam Masyarakat Plural [Islamic Education for Promoting Peace within A Plural Society]. Analisis: Jurnal Studi Keislaman, 14(2), 289-309. Retrieved from http://ejournal.iainradenintan.ac.id/index.php/analisis/article/view/605/495 
Bertschy, F., Künzli, C., \& Lehmann, M. (2013). Teachers' Competencies for the Implementation of Educational Offers in the Field of Education for Sustainable Development. Sustainability, 5(12), 5067-5080. doi:10.3390/su5125067

Cashman, T. G. (2007). Malaysian Educators and Their Perspectives on the Iraq War: A Case Study. Research in Comparative and International Education, 2(4), 346-354. doi:10.2304/rcie.2007.2.4.346

Center for Religious Freedom \& Institute for Gulf Affairs. (2006). Saudi Arabia's Curriculum of Intolerance. Washington, D.C.: Center for Religious Freedom.

Chai, C. S., Koh, J. H., Tsai, C.-C., \& Tan, L. L. (2011, August). Modeling Primary School Pre-Service Teachers' Technological Pedagogical Content Knowledge (TPACK) for Meaningful Learning with Information and Communication Technology (ICT). Computers \& Education, 57(1), 1184-1193. doi:10.1016/j.compedu.2011.01.007

Chordnork, B., \& Yuenyong, C. (2014, February 21). Constructing CoRe as a Methodological for Capturing Pedagogical Content Knowledge: A Case Study of Thailand Teachers Teaching Global Warming. Procedia - Social and Behavioral Sciences, 116, 421-425. doi:10.1016/j.sbspro.2014.01.233

Clément, P. (2015). Muslim Teachers' Conceptions of Evolution in Several Countries. Public Understanding of Science, 24(4), $400-421$. doi:10.1177/0963662513494549

Daun, H., \& Arjmand, R. (2005). Islamic Education. In J. Zajda (Ed.), International Handbook on Globalisation, Education and Policy Research (pp. 377-388). Dordrecht, The Netherlands: Springer.

Gay, L., Mills, G. E., \& Airasian, P. (2012). Educational Research : Competencies for Analysis and Applications (10th ed.). New Jersey, the United States: Pearson Education, Inc.

Graham, C. R. (2011, November). Theoretical Considerations for Understanding Technological Pedagogical Content Knowledge (TPACK). Computers \& Education, 57(3), 1953-1960. doi:10.1016/j.compedu.2011.04.010

Hanafi, Y. (2011, September). Bias-bias Dikotomi dalam Buku Ajar Matakuliah Pendidikan Agama Islam di Perguruan Tinggi Umum [Dichotomy Biases in Islamic Education Textbooks in General Higher Education]. Islamica: Jurnal Studi Keislaman, 6(1), 153167. Retrieved from http://islamica.uinsby.ac.id/index.php/islamica/article/view/123/116

Hidayat. (2012). Model Pembelajaran Pendidikan Agama Islam Berorientasi Pengembangan Karakter Bangsa [A Model of Nation Characteristics Development Oriented Islamic Education Teaching]. Jurnal el-Hikmah Fakultas Tarbiyah UIN Malang, IX(2), 150166. Retrieved from http://ejournal.uin-malang.ac.id/index.php/elhikmah/article/view/2260

Hutchinson, S. R. (2004). Survey Research. In K. deMarrais, \& S. D. Lapan (Eds.), Foundations for Research: Methods of Inquiry in Education and the Social Sciences (pp. 283-301). New Jersey: Lawrence Erlbaum Associates Publishers.

Jourdan, D., Pironom, J., Berger, D., \& Carvalho, G. (2012). Factors Influencing Teachers' Views of Health and Health Education: A Study in 15 Countries. Health Education Journal, 72(6), 660-672. doi:10.1177/0017896912459821

Kleickmann, T., Richter, D., Kunter, M., Elsner, J., Besser, M., Krauss, S., \& Baumert, J. (2013, January/February). Teachers' Content Knowledge and Pedagogical Content Knowledge: The Role of Structural Differences in Teacher Education. Journal of Teacher Education, 64(1), 90-106. doi:10.1177/0022487112460398

Matsumoto, Y. (2008). Education for Demilitarizing Youth in Post-Conflict Afghanistan. Research in Comparative and International Education, 3(1), 65-78. doi:10.2304/rcie.2008.3.1.65

Mirza, K., \& Bakali, N. (2010). Islam: The Fundamentals Every Teacher Should Know. Counterpoints, 346 (Teaching Against Islamophobia), 49-64. Retrieved from http://www.jstor.org/stable/42980510

Mukminan. (2010, November ). Analisis Kecukupan Guru Pendidikan Agama Islam Sekolah Dasar di Kabupaten Bantul [Analysis of Elementary Schools Islamic Education Teachers Adeqaucy in Bantul Regency]. Jurnal Kependidikan, 40(2), 165-174. Retrieved from http://journal.uny.ac.id/index.php/jk/article/view/496

Pohl, F. (2015, May 20). Indonesia, Islamic Education in. Retrieved from Oxford Islamic Studies Online: http://www.oxfordislamic studies.com/article/opr/t343/e0029

Rasyidin, A. (2010, Desember). Bias Gender dalam Buku Pendidikan Agama Islam Sekolah Dasar [Gender Biases in the Islamic Education Textbooks in Elementary Schools]. Jurnal Penelitian Keislaman, 7(1), 81-114. Retrieved from http://ejurnal. iainmataram.ac.id/index.php/lemlit/article/view/94

Republika. (2015, April 17). Ajarkan Kekerasan, Buku Pendidikan Agama Islam Ditarik [Spreading Hatred, Islamic Education Textbooks Drawn from Circulation]]. Retrieved from Republika Online: http://www.republika.co.id/berita/pendidikan/eduaction/15/04/17/ nmwfpr

Rokhmad, A. (2012, May). Radikalisme Islam dan Upaya Deradikalisasi Paham Radikal [Islamic Radicalism and Deradicalisation Efforts of Radical Religious Thoughts]. Walisongo: Jurnal Penelitian Sosial Keagamaan, 20(1), 79-113. Retrieved from http://journal. walisongo.ac.id/index.php/wali/article/view/43/43

Sahlan, A. (2011). Pembelajaran Pendidikan Agama Islam dengan Pendekatan Kontekstual [Islamic Education Teaching with Contextual Approach]. Jurnal el-Hikmah Fakultas Tarbiyah UIN Malang, VIII(2), 217-227. Retrieved from http://ejournal.uin-malang.ac.id/ index.php/elhikmah/article/view/2241

Salamah, H. (2013, December 24). Pendidikan Multikultural: Upaya Membangun Keberagaman Inklusif di Sekolah [Multicultural Education: Efforts to Develop Inclusive Diversity in School]. Retrieved from FTK UIN Sunan Ampel: http://fitk.uinsby.ac.id/30karya-tulis/83-pendidikan-multikultural-upaya-membangun-keberagaman-inklusif-di-sekolah.html

Samsuddin. (2012, September). Format Baru Transformasi Pendidikan Islam [New Form of Islamic Education Transformation]. Islamica: Jurnal Studi Keislaman, 7(1), 161-185. Retrieved from http://islamica.uinsby.ac.id/index.php/islamica/article/view/133/123

Schneider, R. M., \& Plasman, K. (2011, December). Science Teacher Learning Progressions: A Review of Science Teachers' 
Pedagogical Content Knowledge Development. Review of Educational Research, 81(4), 530-565. doi:10.3102/00346543114233 82

Schwab, J. (1978). Science, Curriculum and Liberal Education. Chicago: University of Chicago Press.

Shapiro, G. M. (2008). Sample Size. In P. J. Lavrakas (Ed.), Encyclopedia of Survey Research Methods (Vol. 2, pp. 781-783). Thousand Oaks, California: SAGE Publications, Inc.

Shulman, L. S. (1986, February). Those Who Understand: Knowledge Growth in Teaching. Educational Researcher, 15(2), 4-14. Retrieved from http://www.jstor.org/stable/1175860

Stoilescu, D. (2015, March 26). A Critical Examination of the Technological Pedagogical Content Knowledge Framework: Secondary School Mathematics Teachers Integrating Technology. Journal of Educational Computing Research, 1-34. doi:10.1177l 0735633115572285

Suneti, R. (2012, January-June). Implementasi Pembelajaran Pendidikan Agama Islam Berwawasan Rekontruksi Sosial [Implementation of Social Reconstruction Concept in Islamic Education Teaching]. Madrasah, 4(2), 243-258. Retrieved from http://ejournal.uinmalang.ac.id/index.php/tarbiyah/article/view/2184

Susanto, E. (2009). Pendidikan Agama Islam; Antara Tekstualis Normatif dengan Kontekstualis Historis [Islamic Education; Between Normative-Textual and Historic-Contextual]. Tadrîs: Jurnal Pendidikan Islam, 4(2), 172-191. Retrieved from http://www.ejournal. stainpamekasan.ac.id/index.php/tadris/article/view/251/242

Syafi'i, A. (2012, January-July). Pendekatan Hermeneutik dalam Pembelajaran Pendidikan Agama Islam [Hermeneutic Approach in Islamic Education Teaching]. Tarbiyatuna: Jurnal Penelitian dan Pendidikan Islam, 2(2), 1-16. Retrieved from http://118.97.15. 162/index.php/fai/article/view/53

Tsangaridou, N. (2002, February). Enacted Pedagogical Content Knowledge in Physical Education: a Case Study of a Prospective Classroom Teacher. European Physical Education Review, 8(1), 21-36. doi:10.1177/1356336X020081002

Yurdakul, I. K., Odabasi, H. F., Kilicer, K., Coklar, A. N., Birinci, G., \& Kurt, A. A. (2012, April). The Development, Validity and Reliability of TPACK-Deep: A Technological Pedagogical Content Knowledge Scale. Computers \& Education, 58(3), 964-977. doi:10.1016/j. compedu.2011.10.012 